\title{
Protective Effect of Cinnamomum tamala Extract on Gentamicin-Induced Nephrotic Damage in Rabbits
}

\author{
Naveed Ullah ${ }^{1^{*}}$, Mir Azam Khan ${ }^{1}$, Taous Khan ${ }^{2}$ and Waqar Ahmad ${ }^{1}$ \\ ${ }^{1}$ Department of Pharmacy, University of Malakand, Chakdara, ${ }^{2}$ Department of Pharmacy, COMSATS Institute of Information \\ Technology, Abbottabad Pakistan.
}

*For correspondence: E-mail: naveedjia@yahoo.com, naveedullahpharmacist@gmail.com; Tel: 0092-3455910522

Received: 1 February 2013

Revised accepted: 29 March 2013

\begin{abstract}
Purpose: To investigate the reno-protective properties of Cinnamomum tamala against gentamicininduced nephrotoxicity in rabbits.

Methods: Rabbits were randomly divided into four groups $(n=6)$ including Group-1 (normal saline), Group-2 (gentamicin, 80 mg/kg/day), Group-3 (C. tamala, 200 mg/kg/day) and Group-4 (gentamicin, 80 $\mathrm{mg} / \mathrm{kg} / \mathrm{day}$ and C. tamala, $200 \mathrm{mg} / \mathrm{kg} /$ day). Body weight, blood urea nitrogen, serum creatinine, creatinine clearance, serum uric acid, urinary volume and urinary protein excretion were measured followed by histological examination.

Results: Gentamicin-treated animals showed significant renal damage as indicated by rise in blood urea nitrogen $(54.18 \pm 2.60 \mathrm{mg} / \mathrm{dl})$, serum creatinine $(4.02 \pm 0.14 \mathrm{mg} / \mathrm{dl})$, serum uric acid $(2.34 \pm 0.12$ $\mathrm{mg} / \mathrm{dl})$, urinary proteins $(3.86 \pm 0.32 \mathrm{mg} / \mathrm{dl})$ and decrease in creatinine clearance $(0.76 \pm 0.09 \mathrm{ml} / \mathrm{min})$, urinary volume (126.00 $\pm 9.09 \mathrm{ml}$ ) and body weight (10.80 $\pm 1.09 \%)$. However, animals treated with gentamicin and C. tamala significantly protected rabbit kidney from structural and functional changes associated with gentamicin.

Conclusion: Based on the findings, it is apparent that concurrent administration of $200 \mathrm{mg} / \mathrm{kg} / \mathrm{day}$ of C. tamala leaf extract and gentamicin effectively prevented gentamicin-induced renal damage.
\end{abstract}

Keywords: Cinnamomum tamala, Renal protection, Gentamicin, Renal damage

Tropical Journal of Pharmaceutical Research is indexed by Science Citation Index (SciSearch), Scopus, International Pharmaceutical Abstract, Chemical Abstracts, Embase, Index Copernicus, EBSCO, African Index Medicus, JournalSeek, Journal Citation Reports/Science Edition, Directory of Open Access Journals (DOAJ), African Journal Online, Bioline International, Open-J-Gate and Pharmacy Abstracts

\section{INTRODUCTION}

Cinnamomum tamala (Lauraceae) is commonly known as tejpat and tejpatra in Sanskrit [1]. The plant is widely found in Asia and Australia [2] and its major constituents are a-pinene, myrcene, camphene, $p$-cymene, limonene, eugenol and methyl eugenol [3]. The plant has different medicinal properties like carminative, diuretic, anti-flatulent effects and is also useful in heart abnormalities [2]. The usefulness of $C$. tamala in the treatment of anorexia, nausea, mouth dryness, diarrhea and bladder disorder has also been described [4]. The plant possesses hypolipidemic and hypoglycemic properties [5] and has potent antibacterial activity against Escherichia coli, Bacillus subtilis and Saccharomyces cerevisiae [6]. C. tamala has been used in folk medicine as brain tonic and anthelmintic especially for the treatment of anal and rectal diseases [1]. It is reported that $C$. tamala leaves have gastro-protective effects in experimental animals, may be because of free radical scavenging properties [7]. The plant has also been reported with high phenolic contents and has concentration-dependent antioxidant activities [8]. In view of this, the plant extract may 
inhibit oxidative damage and protect against gentamicin-induced renal toxicity. The objective of the present study, therefore, was to investigate the renal-protective activity of $C$. tamala against gentamicin toxicity.

\section{EXPERIMENTAL}

\section{Plant material and extraction}

C. tamala leaves were collected from Northern areas of Pakistan in the year 2010. Following authentification by Professor Umar Farooq, Department of Botany, Postgraduate College No.1, Abbottabad, Pakistan, a voucher specimen was deposited in the herbarium of the same department.

The fresh leaves were washed, shade-dried and ground with a grinder (ZK-115, Japan). Extraction was done with sufficient quantity of 70 $\%$ ethanol with intermittent stirring for three weeks. The mixture was filtered and the supernatant evaporated using a rotary evaporator (R-210 Germany) [9].

\section{Experimental protocol}

Four groups of animal, each having six male rabbits of similar weights, were acclimatized for 15 days before the start of study in the animal house of Frontier Medical and Dental College, Abbottabad, Pakistan. All the rabbits were maintained on the same diet and $12 \mathrm{~h}$ light/dark cycle. Animal handling and care was strictly according to the rules and regulations of University of Malakand, along with international laws and policies (National Institutes of Health Guide for the Care and Use of oratory Animals, $\mathrm{NIH}$ Publication no. 85-23, 1985) after institutional approval of the study by Research Society of the university. The extract was given orally while gentamicin (Merck, Pakistan) was injected intramuscularly to induce nephrotoxicity according to the treatment schedule in Table 1.

Table 1: Daily treatment rabbits for a period of 3 weeks

\begin{tabular}{lll}
\hline $\begin{array}{l}\text { Group } \\
\text { no. }\end{array}$ & $\begin{array}{l}\text { Group } \\
\text { code }\end{array}$ & Treatment \\
\hline 1 & C (control) & $0.9 \%$ saline $(2 \mathrm{ml} / \mathrm{kg}, \mathrm{im})$ \\
2 & G (toxic) & $\begin{array}{l}\text { Gentamicin }(80 \mathrm{mg} / \mathrm{kg}, \mathrm{im}) \\
\text { Gentamicin }(80 \mathrm{mg} / \mathrm{kg} /, \mathrm{im})\end{array}$ \\
3 & GC-ta & $\begin{array}{l}\text { + C. tamala }(200 \mathrm{mg} / \mathrm{kg}, \\
\text { po). }\end{array}$ \\
& & C. tamala $(200 \mathrm{mg} / \mathrm{kg}, \mathrm{po})$. \\
\hline
\end{tabular}

Blood samples were collected three times throughout the experimental period for the estimation of serum creatinine, creatinine clearance, blood urea nitrogen and serum uric acid. Urine was also collected from the mesh beneath the cages on days 0,11 and 21 for the assessment of urinary creatinine, urinary protein and urinary volume. The body weight of each rabbit was measured with digital balance (Excel, China) three times throughout the study period.

Determination of blood urea nitrogen (BUN) was performed by Bertholot's indophenol procedure, using a reagent kit (ProDia International, UAE), while determination of serum creatinine and urinary creatinine was performed by the Jaffe reaction [10]. Chemistry analyzer (Power Lab 300, Merck, Germany) was used for the evaluation of serum uric acid using a commercially available kit (ProDia International, UAE) [10].

\section{Renal histopathology}

On the last day of experiment, half of the rabbits in each group were sacrificed. The kidneys were isolated and cut longitudinally and transversely; and fixed in $10 \%$ formal-saline solution. The tissues were dehydrated with ethanol in the following alcohol concentration sequence: 50,70 and $90 \%$. Finally, the absolute alcohol was applied, after using xylene solution for clearing purpose. The tissues were then fixed with help of paraffin wax. Rotatory microtome (Micros, Germany) was used for the sectioning of solidified blocks. The slides were stained with hematoxylin and eosin dyes and examined with a light microscope.

\section{Statistical analysis}

One-way ANOVA was used for comparison of groups following Dunnett test using Graph Pad Prism (version-5) software. The results were expressed as Mean \pm SEM. Statistical significance was assumed at $P$-value less than 0.05 .

\section{RESULTS}

\section{Changes in body weight}

Gentamicin treated animals lost $10.795 \pm 1.09 \%$ of body weight significantly different from control group animals $0.155 \pm 0.91 \%, P<0.0001$. Further, animals treated with C. tamala lost 0.95 $\pm 0.67 \%$ of body weight while animals treated with simultaneous administration of $C$. tamala and gentamicin lost Lab $1.26 \pm 0.30 \%$ of body weight significantly different from gentamicin treated animals $(P<0.0001)$ as given in Table 2 . 
Table 2: Mean body weight (mean \pm SEM, $n=6$ ) of rabbits on days 0,11 and 21

\begin{tabular}{|c|c|c|c|c|}
\hline \multirow[t]{2}{*}{$\begin{array}{l}\text { Treatment } \\
\text { group }\end{array}$} & $\begin{array}{l}\text { Day } \\
0\end{array}$ & Day 11 & $\begin{array}{l}\text { Day } \\
21\end{array}$ & \multirow{2}{*}{$\begin{array}{l}\text { Weight } \\
\text { loss } \\
(\%)\end{array}$} \\
\hline & \multicolumn{3}{|c|}{$\begin{array}{c}\text { Weight } \\
\text { (kg) }\end{array}$} & \\
\hline $\mathrm{C}$ & 1.312 & 1.308 & 1.310 & $\begin{array}{l}0.16 \pm \\
0.91^{* * *}\end{array}$ \\
\hline$G$ & 1.210 & 1.166 & 1.080 & $\begin{array}{l}10.80 \pm \\
1.09\end{array}$ \\
\hline GC-ta & 1.302 & 1.295 & 1.286 & $\begin{array}{l}1.26 \pm \\
0.30^{* *}\end{array}$ \\
\hline C-ta & 1.258 & 1.252 & 1.246 & $\begin{array}{l}0.95 \pm \\
0.67^{* \star *}\end{array}$ \\
\hline
\end{tabular}

${ }^{* *} p<0.05,{ }^{* * *} p<0.001$ denote significantly different compared with control

\section{Blood urea nitrogen (BUN)}

Blood orea nitrogen was elevated in gentamicintreated animals on day $11(37.78 \pm 2.14 \mathrm{mg} / \mathrm{dl}$ compared with control $13.75 \pm 1.04 \mathrm{mg} / \mathrm{dll}(p<$ $0.0001)$ and on day $21(54.18 \pm 2.6 \mathrm{mg} / \mathrm{dl}$ compared with control $14.14 \pm 1.12 \mathrm{mg} / \mathrm{dl}, p<$ 0.0001). Further, group GC-ta and C-ta was significantly different compared with gentamicitreated animals $p<0.0001$ ) as given in Table 3 .

\section{Serum creatinine}

Serum creatinine increased significantly in gentamicin treated animals on day $11(1.96 \pm$ $0.14 \mathrm{mg} / \mathrm{dl}$ compared with control $0.71 \pm 0.10$ $\mathrm{mg} / \mathrm{dl}, p<0.0001)$ and further increased on day $21(4.02 \pm 0.14 \mathrm{mg} / \mathrm{dl}$ compared with control 0.80 $\pm 0.10 \mathrm{mg} / \mathrm{dl}, p<0.0001)$. Group GC-ta and C-ta was significantly different compared with gentamicin treated animals $(p<0.0001)$ as given in Table 3.

\section{Creatinine clearance}

Creatinine clearance decreased significantly in gentamicin treated animals on day $11(2.08 \pm$ $0.25 \mathrm{ml} / \mathrm{min}$ compared with control $5.08 \pm 0.82$ $\mathrm{ml} / \mathrm{min}, p=0.0058$ ) and further decreased on day $21(0.76 \pm 0.09 \mathrm{ml} / \mathrm{min}$ compared with control $4.99 \pm 1.16 \mathrm{ml} / \mathrm{min}, p=0.0047)$. Group GC-ta and $C$-ta was significantly different compared with gentamicin treated animals on day 21 ( $p<$ 0.0001 ) as given in Table 3.

\section{Serum uric acid}

Serum uric acid was significantly elevated in gentamicin treated animals on day $21(2.34 \pm$ $0.12 \mathrm{mg} / \mathrm{dl}$ compared with control $1.51 \pm 0.02$ $\mathrm{mg} / \mathrm{dl}, p=0.0058)$. Further, serum uric acid of group GC-ta and C-ta was significantly different compared with gentamicin treated animals $(p=$
0.0013 and $<0.0001$, respectively) as given in Table 3.

Table 3: Serum BUN, creatinine, creatinine clearance and uric acid on day 21 for all animal groups

\begin{tabular}{|c|c|c|c|c|}
\hline Group & $\begin{array}{c}\text { BUN } \\
\text { (mg/dl) }\end{array}$ & $\begin{array}{c}\text { Serum } \\
\text { creatinine } \\
\text { (mg/dl) }\end{array}$ & $\begin{array}{c}\text { Creatinin } \\
\text { e } \\
\text { clearanc } \\
e \\
e \\
\text { (ml/min) }\end{array}$ & $\begin{array}{l}\text { Serum } \\
\text { uric } \\
\text { acid } \\
(\mathrm{mg} / \mathrm{dl})\end{array}$ \\
\hline $\mathrm{C}$ & $\begin{array}{l}14.14 \pm \\
1.12^{\text {*** }}\end{array}$ & $\begin{array}{l}0.80 \pm \\
0.10^{\star * *}\end{array}$ & $\underset{* * *}{4.99 \pm 1.16}$ & $\begin{array}{c}1.51 \pm 0.0 \\
2^{* * *}\end{array}$ \\
\hline G & $\begin{array}{c}54.18 \pm 2 . \\
60\end{array}$ & $4.02 \pm 0.14$ & $0.76 \pm 0.09$ & $\begin{array}{c}2.34 \pm 0.1 \\
2\end{array}$ \\
\hline GC-ta & $\begin{array}{c}16.75 \pm 2 . \\
58^{* \star *}\end{array}$ & $\underset{*}{1.21 \pm 0.09^{* *}}$ & $\underset{* * *}{3.53 \pm 0.43}$ & $\begin{array}{c}1.56 \pm 0.1 \\
3^{* *}\end{array}$ \\
\hline C-ta & $\begin{array}{c}13.26 \pm 0 . \\
89^{* \star *}\end{array}$ & $\underset{*}{0.83 \pm 0.05^{* *}}$ & $\underset{* * *}{4.71 \pm 0.52}$ & $\begin{array}{c}1.23 \pm 0.1 \\
0^{* * *}\end{array}$ \\
\hline
\end{tabular}

\section{Urinary protein}

Urinary protein increased significantly in gentamicin treated animals on day 11 (2.51 \pm $0.30 \mathrm{mg} / \mathrm{dl}$ compared with control $1.64 \pm 0.17$ $\mathrm{mg} / \mathrm{dl}, p=0.0329$ ), and further increased on day 21 (3.86 $\pm 0.32 \mathrm{mg} / \mathrm{dl}$ compared with control 1.81 $\pm 0.22 \mathrm{mg} / \mathrm{dl}, p=0.0004)$. Further, Group GC-ta and C-ta was significantly different from gentamicin treated animals on day 21 of study period ( $p=0.0002$ and 0.0013 respectively) as shown in Fig 1.

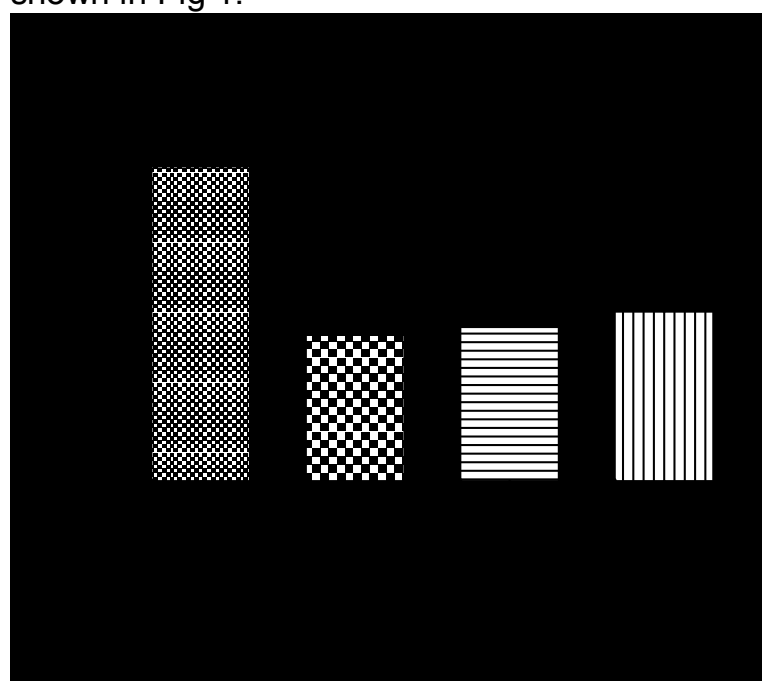

Fig 1: Terminal urinary protein excretion (day 21)

\section{Urinary volume}

Urinary volume of gentamicin treated animals was statistically unchanged on day 11 (168 \pm $11.96 \mathrm{ml}$ compared with control $200 \pm 9.16 \mathrm{ml}, P$ $=0.0596$ ). However on day 21 it was significantly decreased $(126 \pm 9.09 \mathrm{ml}$ compared with control $217 \pm 19.77 \mathrm{ml}, P=0.0019$ ). Further, urinary volume of group GC-ta and C-ta was 
significantly different from gentamicin treated animals on day $21(P=0.0003$ and 0.0002 respectively) as shown in Fig 2.

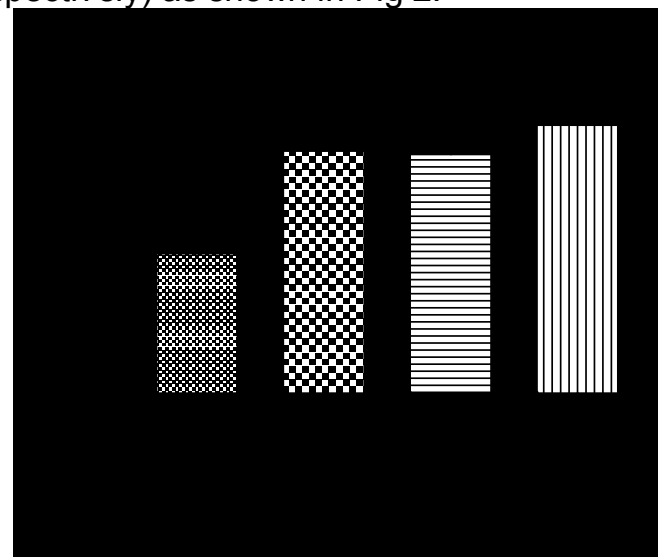

Fig 2: Twenty four- (24-) hour urine volumes of groups on day $21 ;{ }^{* * *} p<0.05$ compared with control

\section{Renal histopathology}

Most of toxic group animals showed ruptured tubular cells with hydropic changes as shown in Fig 3C. Cellular pattern was lost with the presence of necrosis, mostly detected in the proximal tubules (Fig 3C). Atropy of glomeruli with increased cellularity was also found in gentamicin treated animals. Few ruptured tubules were also seen in the medulla of group GC-ta and gentamicin treated animals (Fig 3D, $F)$. The number of ruptured and necrotic cells diagnosed in other groups was not significant when compared with the toxic group (Fig 3A, B, $E, G, H)$.
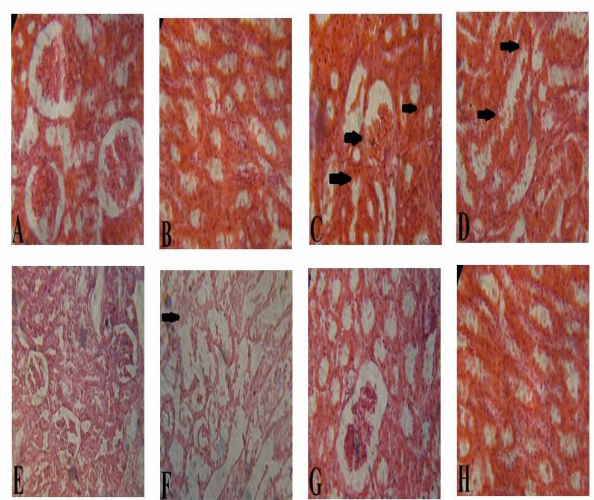

Fig 3: Photomicrographs of kidney sections $(H \& E \times$ 200): (A) renal cortex of control group presenting normal glomerular structures. (B) renal medulla of control group presenting normal tubules. (C) renal cortex of gentamicin treated group showing glomerular and proximal tubular necrosis. (D) renal medulla of gentamicin treated group presenting ruptured tubules and hydropic changes. (E) renal cortex of group GC-ta presenting normal glomeruli. $(F)$ renal medulla of group GC-ta showing some ruptured tubules $(\mathrm{G})$ renal cortex of group C-ta presenting normal structures $(\mathrm{H})$ renal medulla showing normal tubules.

\section{DISCUSSION}

The present study was aimed to investigate the nephroprotective potentials of $C$. tamala against gentamicin-induced toxicity. Renal damage caused by gentamicin depends upon the dose and duration of the treatment. Different researchers used different doses, ranging between 8 and $80 \mathrm{mg} / \mathrm{kg} /$ day to produce renal damage [11]. However, these toxic effects are only associated if the drug is taken five to ten times normal doses [12, 13]. Therefore, in the current study we used a daily dose of $80 \mathrm{mg} / \mathrm{kg}$ of gentamicin for a period of 21 days to produce significant nephrotoxic effects.

Rise in serum creatinine and necrosis of tubules have been reported in animals given daily doses of $30-60 \mathrm{mg} / \mathrm{kg}$ gentamicin for $5-10$ days [1214]. Elevation in BUN and serum creatinine and significant fall in creatinine clearance has been reported with the toxic use of gentamicin [14] which was in agreement with the current findings for gentamicin treated animals. The protective role of C. tamala extract can easily be concluded from current results.

Gentamicin treated animals significantly lost their body weight compared with control group. However, extract-treated animals did not show significant loss in their body weight when compared with gentamicin treated animals. The blocking of tubules by necrotic debris and leaking of filtrate through the ruptured tubules might be responsible for the rise in serum creatinine [15]. However, it has also been reported that tubular necrosis and alteration in renal function parameters are independent of each other $[14,16]$.

A significant fall in urinary volume and rise in urinary protein was observed in gentamicintreated animals which were significantly different from those of control and extract-treated groups; this is suggestive of the protection afforded by $C$. tamala. In the current study, histopathological examination of kidney revealed the presence of regenerating cells, necrosis and hydropic changes in gentamicin-treated animals as reported previously $[13,17,18]$. Elevation of protein excretion may due to cellular degeneration caused by the accumulation of hyaline and granular casts in the proximal tubules. The blockade of tubules by cast cells may be a reasonable cause for the induction of nephrotoxicity associated with gentamicin $[15,18]$. The fact that there were no significant necrosis, derangement of cells, hydropic changes and hyaline were detected in control 
and extract-treated animals confirms the protective role of plant extract.

\section{CONCLUSION}

Increase in serum creatinine, blood urea nitrogen and serum uric acid, and fall in creatinine clearance with morphological changes, usually induced by gentamycin, can be prevented by coadministration of $C$. tamala and gentamicin.

\section{ACKNOWLEDGEMENT}

Higher Education Commission Pakistan is acknowledged for their financial support for this work.

\section{COMPETING INTERESTS}

The authors declare no conflict of interest

\section{REFERENCES}

1. Kirtikar KR, Basu BD. Cinnamomum tamala. In: Blatter E. Caius JF, Mhaskar KS, editors. Indian Medicinal Plants. 2nd edn. India: L.M.B. Publishers, 1995; pp 2146-2147.

2. Showkat RM, Mohammed $A$, Kapoor $R$. Chemical composition of essential oil of Cinnamomum tamala Nees and Eberm leaves. Flavour Frag $J$ 2004: 19: 112-114.

3. Siano F, Ghizzoni C, Gionfriddo F, Colombo E, Servillo $L$, Castaldo D. Determination of estragol, safrole and eugenol methyl ether in food products. Food Chem 2003; 81: 469-475.

4. Kapoor LD. CRC handbook of Ayurvedic medicinal plants. Florida: CRC press-Boca Raton; 2000. $p$ 117.

5. $\operatorname{Kar}$ A, Choudhar BK, Bandyopadhyay NG. Comparative evaluation of hypoglycemic activity of some Indian medicinal plants in alloxan diabetic rats. $J$ Ethnopharmacol 2003; 84: 105-108.
6. De M, De AK, Banerjec AB. Antimicrobial screening of some Indian spices. Phytother Res 1999; 13: 616618.

7. Eswaran $M B$, Surendran S, Vijayakumar M, Ojha SK, Rawat AK, Rao ChV. Gastroprotective activity of Cinnamomum tamala leaves on experimental gastric ulcers in rats. J Ethnopharmacol 2010; 128: $537-540$.

8. Chakraborty $U$, Das $H$. Antidiabetic and antioxidant activities of Cinnamomum tamala leaf extracts in STZ-treated diabetic rats. Global J Biotech Biochem 2010; 5:12-18.

9. Njamen $D$, Nkeh-Chungag BN, Tsala E, Fomum ZT, Mbanya JC, Ngufor GF. Effect of Bridelia ferruginea (Euphorbiaceae) leaf extract on sucrose-induced glucose intolerance in rats. Trop J Pharm Res 2012; 11: 759-765.

10. Smith ST. Non-protein nitrogen. In: Bishop ML, DubenVon Laufen JH, Fody EP, editors. Clinical Chemistry: Principles, procedures, correlations. Philadelphia: JB Lippincott Company; 1985; pp 411-423.

11. Lee SM, Michael UP. The protective effect of nitrindipine on gentamicin-induced renal failure in rats. Exp Mol Path 1985; 43: 107-114.

12. Tulkens PM. Nephrotoxicity of aminoglycoside antibiotics. Toxicol Letters 1989; 46: 107-123.

13. Bennett WM, Elzinger LW, Porter GA. Tubulo-interstitial disease and toxic nephropathy. In: Brenner BM, Rector JRFC, editors. The Kidney. Philadelphia: WB Saunders Company, 1991; pp 1451-1495.

14. Bennett WM, Plamp CE, Parker RA, Gilbert DN, Houghton DC, Porter GA. Alteration in organic ion transport induced by gentamicin nephrotoxicity in rat. J Lab Clin Med 1980; 95: 32-39.

15. Solez K. Pathogenesis of acute renal failure. In: International review of experimental Pathology. New York: Academic Press, 1983; pp 321-326.

16. Luft FC, Yum MN, Kleit SA. The effect of concomitant mercuric chloride and gentamicin on kidney function and structure of rat. J Lab Clin Med 1997; 89: 622-631.

17. Cronin RE, Bulger RE, Southern P, Henrich WL. Natural history of aminoglycoside nephrotoxicity in the dog. J Lab Clin Med 1980; 95: 463-474.

18. Houghton DC, Lee D, Gilbert DN, Bennett WM. Chronic gentamicin nephrotoxicity, continued tubular injury with preserved glomerular filteration. Am J Pathol 1986; 123: 183-194. 